\title{
Utilization of cactus pear fruits' pulp planted under severe drought conditions as source of natural pigments and antioxidant in cake making
}

\author{
Mahmoud Elwakeel $^{1 *}$, Mohamed Hassan Hosny ${ }^{2}$, Mohamed Rashad ${ }^{3}$ and Maha Elbana ${ }^{4}$ \\ ${ }^{1}$ Food Science Department, Faculty of Agriculture, Beni-Suef University, Beni-Suef, Beni-Suef 62511, \\ Egypt \\ ${ }^{2}$ Food Technology Research Institute, Agricultural Research Center, Egypt \\ ${ }^{3}$ Land and Water Technologies Department, Arid Lands Cultivation Research Institute, City of Scientific \\ Research and Technological Applications (SRTA-City), New Borg Elarab, Alexandria, Egypt \\ ${ }^{4}$ Soil and Water Science Department, Faculty of Agriculture, Beni-Suef University, Beni-Suef 62511, \\ Egypt \\ * Corresponding author: mahmoud.elwakeel@agr.bsu.edu.eg
}

Received on: 23-8-2021

Accepted on: 3-11-2021

\begin{abstract}
Cactus pear is a dominant crop to arid lands with high nutritional value. The cactus pear fruits are used in food processing as add value to food products. In this study, cactus pears were grown under three irrigation regimes (T1, T2, and T3) where two of them (T2 and T3) implicated severe deficit irrigation conditions on the crop. The relationship between applied irrigation water regimes and fruit physical and chemical properties including antioxidants, pigment and vitamin C content was studied. Also, the aim from this study utilizes cactus pear's pulp (CPP), as additive value, in the processing of wheat flour cupcake. Samples of cupcake were made by adding $20 \%, 40 \%, 60 \%$ and $80 \%$ CPP based on wheat flour weight. Fruits obtained under T2 and T3 treatments had higher color concentration than T1. T2 irrigation regime yielded higher contents of total phenolic and flavonoid (TPC and TFC) than those produced under T3 and T1. Antioxidant activity was the highest in T2. Thus, fruits pulp obtained from T2 was selected for cupcake making. The content of soluble solids was 18 Brix in all treatments. Vit $\mathrm{C}$. was significantly higher $(\mathrm{P} \leq 0.05)$ in $\mathrm{T} 3(56.04 \mathrm{~g} \mathrm{AA} / \mathrm{kg})$ than T1 $(55.42 \mathrm{~g} \mathrm{AA} / \mathrm{kg})$ and T2 $(51.01 \mathrm{AA} / \mathrm{kg})$. The content of betacyanin's in T1 was higher $(0.47 \mathrm{mg} \backslash 100 \mathrm{mg}$ dry weight) in fruits pulp than T2 and T3 $(0.44$ and $0.54 \mathrm{mg} \backslash 100 \mathrm{mg}$ dry weight $)$. Sensory evaluation showed that fortification with $60 \%$ cactus pear pulp had the best sensory characteristics meanwhile cupcakes fortified with $80 \%$ cactus pear pulp was not acceptable.
\end{abstract}

KEYWORDS: cactus pear, antioxidants, betacyanin's, cupcakes, Vit C., physic properties , deficit irrigation.

\section{INTRODUCTION}

Cactus pear (Opuntia ficus-indica) is popular in the Mediterranean (Butera, 2002) It is predominantly consumed fresh but due to technological troubles related to production this expenditure is little (Cassano et al., 2010). The essential functional properties of Cactus pear due to antioxidant activity, phenol and vitamin $\mathrm{C}$ contents (Sumaya-Martinez et al., 2011). Also, it is a good source of ascorbic acid and some compounds i.e., betalains, flavonoids, phenolic acids, and other bioactive constituents such as polyphenols and some pigments (Cayupán et al., 2011) with nutraceutical and functional activity (Cassano et al., 2007) that may help thw art degenerative diseases (Jacob et al., 2008). Total antioxidant activity of cactus pear was established to be double upper compared to that of apple, pear, grape, and tomato and similar to grapefruit and red grape raisin (Livrea and
Tesoriere, 2006) The major part commonly identified fruit of Opuntia is cactus pear, a thinskinned fruit with a sugary pulp and juicy (Barbera et al., 1992). Cactus pear fruits has increased attention over the last two decade for its functional and nutritious characteristics (Piga, 2004). Cactus pear fruit is a rich source of dietary fiber, minerals and phytochemicals for example betacyanin's , $\beta$ caroteno and vitamin C (Albano et al., 2015).

Considered beets as traditionally approved prime sources of betacyanin's and red pigment in several food applications. Thus, cactus pear fruits might be another source for betacyanines Moussaayoub et al. (2011). Consequently, in the present research, betacyanin's impact of cactus pear fruits were evaluated and compared in three applied irrigation regime treatments as novel source of natural source for betacyanin. Betalains and watersoluble nitrogenous pigments were found in the fruit 
starting from the second harvesting season under the three applied irrigation regimes.

The betacyanin's be formed of red and yellow to orange betaxanthines in purple. Btalains show a wide $\mathrm{pH}$ stability beside their antioxidant activity and preventive capacity against selected of some degenerative diseases. (Sakuta, 2014). Cupcakes are type of bakery product which chemically and mechanically leavened bakery products that are consumed in large scale by all ages. (Rodríguez et al., 2006) .

The quality of industrial cupcakes may dramatically change depending on shelf-life and tolerance to staling. The cupcakes shelf-life is mostly from one to four weeks or more, depending on ingredients, packaging, aw and storage temperature. High-quality cupcakes have several properties, including volume, shelf-life, low cake crumb stability, and regularly crumb structure. These properties relying on the balanced ingredients, well mixing of cake dough, steadiness of fluid batters in the initial stage of baking then finally thermal-setting stage. Generally, cakes with higher specific volumes contain lower firmness values (Gómez-Conde et al., 2007).

The quality of a final food product based on the quality of the ingredients and the nature of their interactions.as known that cakes are sorts of airleavened products in the bakery industry. High quality cakes can be characterized as having various features, such as high volume, regularly crumb structure, softness and a long shelf life with ability to staling. The expansion of cake products comes from the volume of air bubbles trapped in the cake dough and the fluid influence in the process. The structure and eating quality of the cakes count on the composition which play a signific ant functional role. additionally, a formula based on added fats further changed the structural qualities of both the dough and the baked cake (Chaiya and Pongsawatmanit, 2011).

Cactus pear pulp are used as coloring, flavoring, and thickness agent (Betancourta et al., 2011). Cakes are the largest bakery product consumed and are always used in parties as well as in different celebrations (Abdelrahman, 2014 .(

Cupcakes are types of the bakery products that are often similar to muffins, but they are sweetened and do not have any cream coating (Romjaun and Prakash, 2013). Nowadays as changes in consumer's eating habits, the production of ready-to-eat convenience foods that are frequently available as small portions products are highly used in all countries. Recently, the demand for foods rich in dietary fiber as well as foods rich in antioxidants has increased, which led to the development of the market for these products (Ajla et al., 2008). Obesity is a serious health problem that threatens health, and as a result, there are a large number of people who suffer from overweight, there for these functional food products are used to maintain weight. (El-Said et al., 1993). Approximately one thousand and two hundred existing plants are rich in dietary fiber and have drawn attention as they contain natural antioxidants and have health benefits. Replacing a percentage of wheat flour in bakery products such as low-calorie bread and cake is one of the distinctive features of these food products. Some defects appear in food products as a result of the increased use of additives and cause some defects in the baking function such as sandy texture and reducing the size of the product during baking. Due to additives dough do not hydrate extensively and so do not soften and mix well in the dough (Gould et al., 1989).

There are more than 9 types of synthetic dyes that have been approved by the Food and Drug Administration, including three types of red color. These synthetic dyes $t$ is usually used in many different foods such as cereal products, candy and ice cream. synthetic dyes found in food products can cause inflammatory response in the body, activation of the immune system in the human body, which leads to an increase of the amount of white blood cells entering the bloodstream. Synthetic dyes contain small molecules, which are able to stick to proteins in body of human. That can reason of troubles in the immune system that's why the immune system finds it problematic to defend and protect the body against them. (Shea, 2020). Some experiments have shown that artificial colors may cause cancerous tumors in the bladder and thyroid gland in mice as well as disturbance in immune system cells that are spread throughout the liver, spleen, and lymphatic system in mice (Kobylewski and Jacobson, 2012).

The current study was carried out to understand the relationship between applied irrigation regimes and fruit quality of cactus pear plant (Opuntia ficusindica). The best obtained fruit quality in terms of natural color and antioxidants' content were used as source of those substances in producing high nutritional value cupcake. The study was carried out, as well, to evaluate the application of different levels of the selected cactus pear fruits' pulp in wheat flour fortification to produce added-value healthy cupcake supported by natural red color and its impact on cake sensory characteristics.

\section{MATERIALS AND METHODS}

\subsection{On-farm experiment setup}

An area of 0.1 ha of a two years old cactus pear field planted in the experimental farm of City of Scientific Research and Technological Applications (SRTA-City), Alexandria, Egypt was selected to 
conduct the experiment. Three irrigation water regimes were tested to understand the relationship between the applied irrigation regime and the produced fruit quality in terms of pigments' concentration, vitamin $\mathrm{C}$ content and antioxidant content. To ensure complete isolation between applied irrigation regime treatments, each treatment plot $\mathrm{w}$ as separated by an $8 \mathrm{~m}$ distance from the other treatment. First irrigation regime (T1) applied water on weekly basis with 12 plant-1. Second (T2) and third (T3) irrigation regimes applied water when soil water content dropped under $35 \%$ and $30 \%$ of field capacity, respectively. Other on-farm management practices were maintained as recommended by the Egyptian Ministry of Agriculture and Land Reclamation. First irrigation application started on August 5th 2019 and the experiment lasted until end of September 2020. Fruits were carefully harvested to avoid any damage to the peel or the skin and prepared for analyses and food processing as will be detailed below .

\subsection{MATERIALS}

\subsubsection{Wheat flour}

Wheat flour ( $72 \%$ extraction) for cake production was obtained from South Cairo Mills Company, Cairo, Egypt.

\subsubsection{Fats}

Butter (trade name, Fern) obtained from IFFCO Company for Oil and Fats Products, Suez City, Egypt.

\subsubsection{Dark red color powder}

Dark red color powder as artificial food grade color was obtained from Kamena Company, Giza, Egypt.

\subsubsection{Cactus pear fruits}

Mature fresh fruits having purple skin free from defects were harvested in the summer season (September 2020) and transported to the Faculty of Agriculture (Beni-Suef Univ.) and Agriculture Research Center (Ministry of Agriculture) laboratories at the cages by equipped car.

\subsubsection{Other materials}

Powdered sugar, eggs, baking powder and vanilla were purchased from the local market.

\subsection{METHODS}

\subsubsection{Physical properties of Cactus pear fruits}

The fruit diameter, length, and peel thick were measured using calipers and the weight was recorded. The pulp was weight and thick peel were separated measure and the of these fractions were recorded (karababa et al., 2004). Fruit shape index was determined according to equation provided by Mashop (2007) as follow: fruit width /fruit length oblong $=0.045-0.55$, Elliptic $=0.56-0.60$, ovoid $=$ $0.70-0.79$ and Round $=0.80-0.89$.

\subsubsection{Total soluble solids (T.S.S)}

Total soluble solids (TSS), were estimated using Abbe refractometer model $1 \mathrm{~T}$ at $20^{\circ} \mathrm{C}$ and expressed as Brix (AOAC, 2012).

\subsubsection{Color measurement}

Color was determination using a Hunter Lab colorimeter (MiniScan XETM, Hunter associates Laboratory Inc., Reston, Virginia, USA), using the D65 illuminant with an angle of observation of 50 $\mathrm{mL}$ of cactus pear fruits pulp sample were tempered to $20^{\circ} \mathrm{C}$ before analysis. Color was recorded using the $\mathrm{CIE}-L * a * b^{*}$ values, where $L^{*}$ indicates lightness $\left(L^{*}=0\right.$ or 100 indicate black and white); the axis of chromaticity between green (-) to red (+), and $b^{*}$ the axis among blue (-) to yellow (+). Numerical values of $L^{*}, \mathrm{a}^{*}$ and $\mathrm{b}^{*}$ (Sapers and Douglas, 1987).

\subsubsection{Hardens of fruits}

Texture analysis was performed with the penetrometers of apiece of cactus pear fruits. The penetrometer data output includes the maximum (M) hardness of cactus pear fruits (measured as $\mathrm{Kg} / \mathrm{cm} 2$ pressure from the constant force penetrometer (Mohr and Mohr, 2000).

\subsubsection{Preparation of Cactus pear fruits pulp}

Purple cactus pear fruits without external injuries were obtained for treatment 2 (T2), washed and manually peeled using a sharp knife. pulp was performed by stirring using a manufacturing blender and then passed through a strainer to remove seeds then pulp kept in jerry cans at $-18^{\circ} \mathrm{C}$.

\subsection{Determination of total phenolic contents (TPC)}

The total phenolic contents (TPC) were appreciation according to the Folin-Ciocalteau method (Zarroug et al., 2015). Briefly, $100 \mu \mathrm{l}$ of methanolic extracts was mixed with $900 \mu 1$ of FolinCiocalteu reagent (diluted 1:10 with water). After 5 min, $0.75 \mathrm{ml}$ of $7 \%$ sodium bicarbonate solution added to the blend and vortexes for 30s. The above solution $w$ as then incubated at $\pm r^{\circ} \mathrm{C}^{\circ}$ for $90 \mathrm{~min}$. Absorbance was determined at $765 \mathrm{~nm}$ using UVVis Shimadzu (UV-1601, PC), spectrophotometer. The total phenolic content was appreciation as gallic acid equivalents (GAE) in comparison to a gallic acid standard curve. All values were expressed as 
mean (mg of gallic acid equivalents/100 mL) $\pm \mathrm{SD}$ for triplicate.

\subsubsection{Preparation of extracts}

$5 \mathrm{~mL}$ of freshly prepared cactus pear pulp were added to $50 \mathrm{ml}$ of $50 \%$ methanol and extracted for one day $(24 \mathrm{~h})$ at room temperature, with magnetically stirring. The suspended Solution was centrifuged at $4500 \times \mathrm{g}$ for $10 \mathrm{~min}$ and filtered the supernatant through a cloth followed by $0.45 \mu \mathrm{m}$ microbial filter. The extracts were then stowed in a dark bottle at $4{ }^{\circ} \mathrm{C}$ for investigation.

\subsubsection{Determination of total flavonoid contents}

Flavonoid in the cactus pear pulp extracts was measured by using spectrophotometer depending on the formation of complex flavonoid-aluminium (Djeridane et al., 2006). One $\mathrm{ml}$ of sample was mixed with one $\mathrm{ml}$ of $2 \%$ (w/v) aluminium chloride solution. After that the extract incubation at room temperature for $15 \mathrm{~min}$, the absorbance of the reaction mixtures was measured at $430 \mathrm{~nm}$ against the blank. Rutin was used as the standard for preparing the calibration curve. The significant result was expressed as rutin equivalents (mg RE/100 mL) and all determinations were performed in 3 replications triplicate.

\subsubsection{DPPH radical scavenging activity}

The free radical scavenging activity of cactus pear pulp extract was determined using DPPH free radical according to Kivrak (2015). The extract solutions with different concentrations $(50,100$ and $150 \mu \mathrm{L})$ than methanolic solution $(120 \mu \mathrm{L})$ holding DPPH radicals $(0.4 \mathrm{mM})$ were incubated at room temperature in darkness for $30 \mathrm{~min}$. Absorbance was measured at $517 \mathrm{~nm}$ using UV-Vis Shimadzu (UV1601, PC) spectrophotometer.

\subsection{Determination of ascorbic acid contents}

Ascorbic acid content of the cactus pear pulp was determined according to Du Toit et al., (2019). The sample was diluted $1: 10$ by $0.4 \%$ oxalic acid. Briefly, $100 \mu \mathrm{L}$ of the cactus pear pulp was blended with $100 \mu \mathrm{L}$ of acetate buffer and $800 \mu \mathrm{L}$ of 2,6 dichloroindophenol sodium sal hydrate (DCPI). The absorbance of the mixing solution was measured at $520 \mathrm{~nm}$ in the microplate reader (Power Wave XS UV-Biotek, software KC Junior, USA), the results were expressed as $\mathrm{mg}$ ascorbic acid per liter of cactus pear pulp (mg AA/L) and use ascorbic acid as a reference standard.

\subsection{Processing of cupcake}

Cupcakes were processed using the method described by the Bakery Pilot Plant in Food Technology Research Institute (FTRI), Agriculture Research Center (ARC). The formulation of cupcake consisted mainly of $200 \mathrm{~g}$ wheat flour (72\% extraction rate), $160 \mathrm{~g}$ sugar, $160 \mathrm{~g}$ fat, $160 \mathrm{~g}$ whole egg, $10 \mathrm{~g}$ dried skim milk, $6.0 \mathrm{~g}$ baking powder, 0.5 $\mathrm{g}$ vanilla and $80 \mathrm{ml}$ water (Table 1). The procedures of processing were as the following: The dry ingredients (i.e., flour, dried skim milk, baking powder and pectin) pectin has been added to improve color distribution in cupcake dough were weighted and sifted together. The butter and sugar were creamed for $1 \mathrm{~min}$ on low speed in a Moulinex mixer model Supermix 150, and then were creamed for additional $1 \mathrm{~min}$ at high speed. Eggs and vanilla were mixed together then added gradually during creaming and all mixture w as creamed for additional 2 min on the high speed.

Table 1. cupcake ingredients (\%) made by using different levels of cactus pear fruits pulp

\begin{tabular}{lllllll}
\hline \multicolumn{1}{c}{ Ingredients } & \multicolumn{5}{c}{ Cupcake formula (\%) } \\
\hline Wheat flour 72\% extraction & $\mathrm{C}-$ & $\mathrm{C}+$ & $\mathrm{C} 1$ & $\mathrm{C} 2$ & $\mathrm{C} 3$ & $\mathrm{C} 4$ \\
Cactus pear pulp & 100 & 100 & 100 & 100 & 100 & 100 \\
Red color powder & - & - & 20 & 40 & 60 & 80 \\
Fat & - & 0.5 & - & - & - & - \\
Powder Sugar & 80 & 80 & 80 & 80 & 80 & 80 \\
Fggs & 80 & 80 & 80 & 80 & 80 & 80 \\
Skim milk & 80 & 80 & 80 & 80 & 80 & 80 \\
Baking powder & 5.0 & 5.0 & 5.0 & 5.0 & 5.0 & 5.0 \\
Pectin powder & 3.0 & 3.0 & 3.0 & 3.0 & 3.0 & 3.0 \\
Vanilla & 1 & 1 & 1 & 1 & 1 & 1 \\
Water & 0.25 & 0.25 & 0.25 & 0.25 & 0.25 & 0.25 \\
\hline C-: control without any addition C+: control using Carmoisine (E-122) as synthetic color & - & - \\
C1:20\% Purple cactus pear pulp (CPP) & C2:40\% Purple cactus pear pulp (CPP) \\
C3:60\% Purple cactus pear pulp (CPP) & C4:80\% Purple cactus pear pulp(CPP) &
\end{tabular}


The dry ingredients and half of the water were added and mixed for $1.5 \mathrm{~min}$. The pulp, and remaining water from last step were added and mixed for an additional $1.5 \mathrm{~min}$. After scraping down the mixing bowl, the batter was mixed for 1 min at high speed. An amount of $45 \mathrm{~g}$ of batter was weighted and placed in cups (upper size $20.5 \times 10.9$ $\mathrm{cm}$, bottom size $17.4 \times 8.3 \mathrm{~cm})$. The cupcakes were baked in oven at for $10 \mathrm{~min}$. After baking, cakes were removed from cups, allowed to cool, then cakes were kept for further examinations.

\subsection{Physical properties of cupcake products}

Physical properties of cupcake as volume $\left(\mathrm{cm}^{3}\right)$, weight $(\mathrm{g})$, specific volume and height $(\mathrm{cm})$ were determined according to A.A.C.C. (2010).

\subsubsection{Texture analysis}

A texture analyzer (Brookfield CT3 Texture Analyzer) Operating Instructions Manual No. M08372-C0113, Stable Micro Systems, USA) was used to determination the texture profile of cupcake in a few terms such as cohesiveness, hardness, springiness, chewiness, resilience and gumminess of the cake samples according to the method described by Gomez et al., (2007).

\subsection{Sensory evaluation of cupcake}

Cakes were judged for cells, texture, crumb color, odor and taste by six panelists as described in A.A.C.C. (2010). Every panelist was asked to test and check how much did he or she like the characteristic under test and also to show their attitude by checking the point that best described their feeling about the characteristic.

\subsection{Statistical analysis}

The Data were expressed as mean values and standard deviation of three (3) determinations by using CoStat, version 3.03for personal computers according to Ott (1988). The Data were analyzed using a one-w ay analysis of variance (ANOVA) and descriptive statistics test. A treatment effect was assumed to be statistically significant at $\mathrm{P}<0.05$.

\section{RESULTS AND DISCUSSION}

\subsection{Irrigation regimes and fruit physical properties}

Physical properties of harvested cactus pear fruits under the different tested irrigation regimes area presented in Table (2). No signific ant difference was found in mean cactus pear fruit weight among the three applied irrigation regimes. It varied between 46.00 to $53.66 \mathrm{~g}$. The fruit pulp weight was higher in T3 )31.04g (than T1 (26.33g) and T2 $(24.33 \mathrm{~g})$ which were all in the acceptable mass range for cactus pear fruits indicated by Stintzing et al., (2005).

No significant difference in fruit peel thickness was found among the three irrigation regimes being of $6 \mathrm{~mm}$ or less. The obtained results confirmed those described by Potgieter and Mkhari (2002). In general, consumers favor a slim peel of less than $5 \mathrm{~mm}$, despite the fact that slim peel is convenient for handling and using Galizzi et al., (2004).

The three applied irrigation regimes resulted in no signific ant difference in fruit shape index. Yet, it indicated an elliptic fruit shape in T1 and T3, while it was ovoid shape in T2. In cactus pear, it has been reported that oval and/or barrel-shaped fruits are easier to handle than elongated fruits and undergo less damage to the stem end during harvesting (Cantwell, 1991). This means that, the obtained fruit yield from all treatments was well qualified for commercialization..

Table 2. Physical properties of cactus pear fruits.

\begin{tabular}{lccccllc}
\hline Treatment & $\begin{array}{c}\text { Fruit } \\
\text { weight }\end{array}$ & $\begin{array}{c}\text { Pulp } \\
\text { weight }\end{array}$ & $\begin{array}{c}\text { peel } \\
\text { weigh }\end{array}$ & $\begin{array}{c}\text { peel } \\
\text { thickness }\end{array}$ & Length & width & $\begin{array}{c}\text { shape } \\
\text { index }\end{array}$ \\
\hline T1 & $53.66 \pm 1.1^{\circ}$ & $26.33 \pm 0.57^{\mathbf{a b}}$ & $27.33 \pm 0.57^{\mathbf{a}}$ & $3.26 \pm 0.25^{\mathbf{a}}$ & $6.0 \pm 0.50^{\mathbf{a}}$ & $3.23 \pm 0.11^{\mathbf{b}}$ & $0.54 \pm 0.02^{\mathbf{b}}$ \\
T2 & $46.0 \pm 2.64^{\mathbf{a}}$ & $24.33 \pm 1.52^{\mathbf{b}}$ & $21.66 \pm 1.15^{\mathbf{a}}$ & $3.26 \pm 0.25^{\mathbf{a}}$ & $4.36 \pm 0.37^{\mathbf{b}}$ & $3.00 \pm 0.10^{\mathbf{c}}$ & $0.69 \pm 0.05^{\mathbf{a}}$ \\
T3 & $\left.51.01 \pm^{\vee} .7\right)^{\mathbf{a}}$ & $31.03 \pm 4.35^{\mathbf{a}}$ & $20.01 \pm 1.07^{\mathbf{b}}$ & $3.01 \pm 0.01^{\mathbf{a}}$ & $5.4 \pm 0.17^{\mathbf{a}}$ & $3.9 \pm 0.1^{\mathbf{a}}$ & $0.72 \pm 0.03^{\mathbf{a}}$ \\
\hline
\end{tabular}

*Average and standard Deviation of three replications

* Means within a row with different letters are significantly different at $\mathrm{P} \leq 0.05$.

\subsection{Nutritional indicators of prepared functional cactus pearl fruits}

Results revealed that cactus pear fruit pulp produced under the three tested irrigation regimes treatments had a high content of betacyanin's. From agricultural point of view, the less the irrigation water applied, the more water saving achieved. Those findings reported in literature approve with the present results shown in Table (2) and fig (1). It may describe the limited use of cactus pear fruits' pulp as commercial source of red colorants till now. Color content and chemical properties of cactus pear fruits under the three applied irrigation regimes are presented in Table (3). I As it could be seen in Table (3), the samples' aqueous solution extracts presented comparatively higher concentrations of betacyanin's, the deep red-violet color of cactus pear pulp unique for these fruits due to high betacyanin contents of cactus pear pulp. 
Table 3. Color concentration and chemical properties of cactus pear fruits pulp.

\begin{tabular}{lllllll}
\hline Treatment & Betacyanin's & $\boldsymbol{a}^{*}$ & $\boldsymbol{L}^{*}$ & $\boldsymbol{b}^{*}$ & $\mathbf{T S S}$ & $\mathbf{p H}$ \\
\hline T1 & $0.47 \pm 0.01^{\mathrm{a}}$ & $13.66 \pm 0.57^{\mathrm{b}}$ & $14.0 \pm 1.0^{\mathrm{b}}$ & $2.66 \pm 0.15^{\mathrm{a}}$ & $18.60 \pm 0.17^{\mathrm{a}}$ & $5.42 \pm 0.04^{\mathrm{a}}$ \\
T2 & $0.44 \pm 0.01^{\mathbf{c}}$ & $18.66 \pm 1.15^{\mathrm{a}}$ & $17.66 \pm 2.08^{\mathrm{a}}$ & $4.00 \pm 1.00^{\mathrm{a}}$ & $18.90 \pm 0.10^{\mathrm{a}}$ & $5.31 \pm 0.11^{\mathrm{a}}$ \\
T3 & $0.45 \pm 0.01^{\mathrm{b}}$ & $16.66 \pm 2.08^{\mathrm{a}}$ & $16.66 \pm 2.08^{\mathrm{a}}$ & $3.33 \pm 1.52^{\mathrm{a}}$ & $19.06 \pm 0.50^{\mathrm{a}}$ & $5.37 \pm 0.16^{\mathrm{a}}$ \\
\hline
\end{tabular}

* Average and s tandard Deviation of three replications

*Means within a row with different letters are significantly different at $\mathrm{P} \leq 0.05$.

HPLC profile (Fig. 1) explain a high impact of betacyanin's in cactus pear fruits pulp in all treatment, whereas all treatments contained betanin as the main betacyanin derivative. The content of betacyanin's in T1 showed the highest value $(0.47$ mg $1100 \mathrm{mg}$ dry weight in fruits pulp compared to 0.44 and $0.54 \mathrm{mg} 1100 \mathrm{mg}$ dry weight for $\mathrm{T} 2$ and $\mathrm{T} 3$ treatments respectively.

Furthermore, the results were obtained confirmed that both, fruits of T2 and T3 have almost the same comparatively a* and $\mathrm{L}^{*}$ values compared to fruits of T1 which showed higher value. Whilst no significant difference was found for $\mathrm{b} *$ value between all treatments. This was coincided with what was found by (Moussa-ayoub et al., 2011).
The content of soluble solids was around to be 18 Brix in all treatments and this is compatible with the obtained results of De Wit et al., (2016).

The ascorbic acid in fruits of $\mathrm{T} 1$ and $\mathrm{T} 3 \mathrm{~h}$ have approximate similar value $(55.42$ and 56.04, respectively), while fruits of $\mathrm{T} 2$ showed lower value (51.01). Du Toit et al., (2019) found the ascorbic acid content, in cactus pear fruits $(>50 \mathrm{mg} / 100 \mathrm{~g})$, this demonstrating higher levels than all treatments. Cactus pear pulp in all treatments had a $\mathrm{pH}$ of around 5.3 (Table 3) which was similar to the results registered by Chavez- Santoscoy et al., (2009). The content of soluble solids, indicated in Table 3, were found to be significantly the same (from 18:19 Brix) at $\mathrm{P} \leq 0.05$.

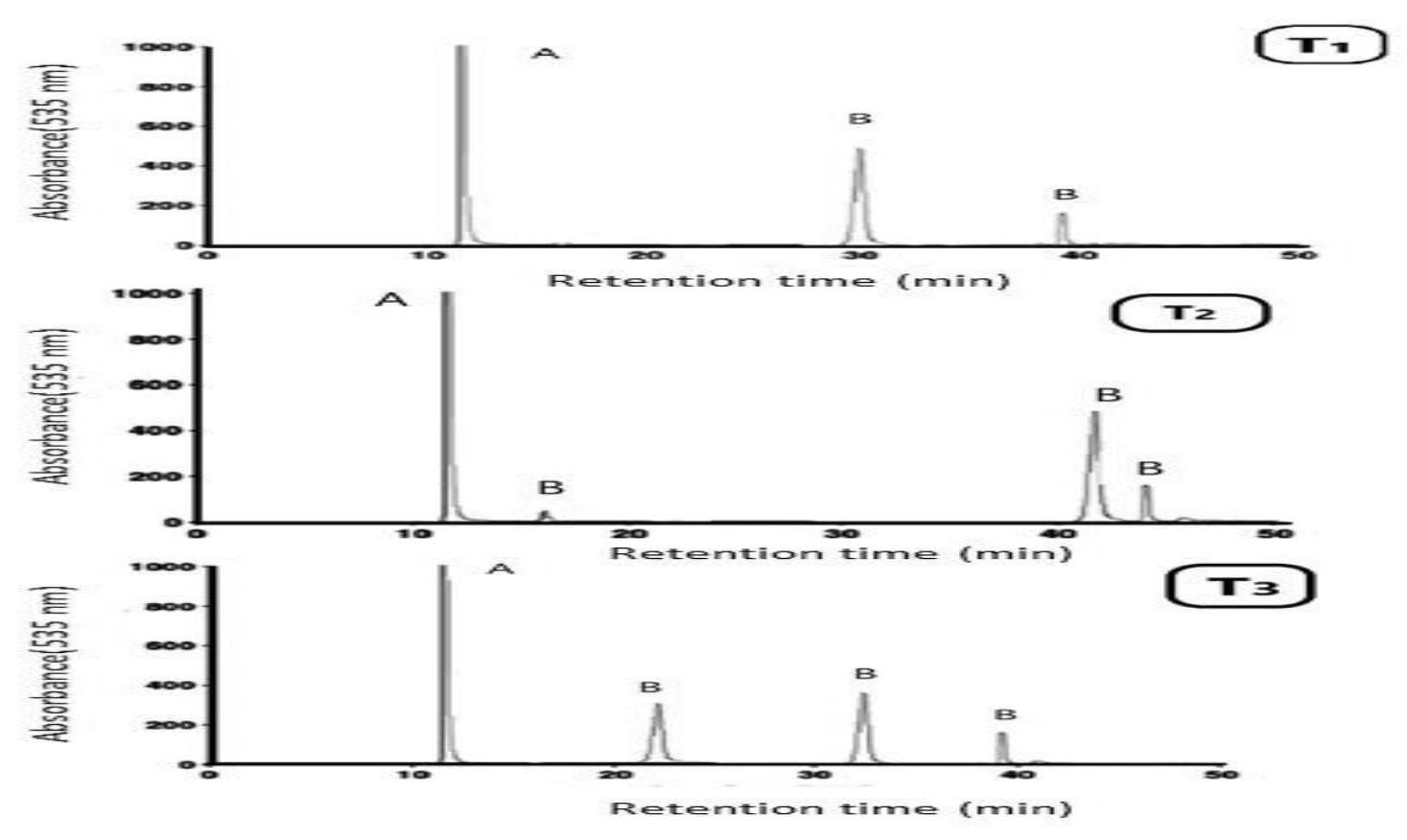

Fig 1. HPLC pattern of betacyanin's from cactus pear fruits pulp in three treatments.

\subsection{TPC, TFC and Vit. C contents of fruits pulp}

Total phenolic contents (TPC) in the cactus pear fruits pulp are indicated in Table 4. It ranged from 104.30 for T1 and T2 to $95.37 \mathrm{mg} \mathrm{GAE} / 100 \mathrm{ml}$, for T3, similar results were reported by Betancourt et al.,2017, they found that total phenolics contents concentration within the pulp were ranged from 11.6 $\mathrm{g}$ to $10.8 \mathrm{gGAE} / \mathrm{kg}$, however Cruz-Cansino et al.,
2015, reported the highest levels varied between 1326.6 and $97 \mathrm{mg} \mathrm{GAE} / \mathrm{kg}$.

In all cases, the cactus pear pulp appeared higher add up to phenolics contents substance than their individual mash. Hence, it was gathered that both vitamin $\mathrm{C}$ and Total phenolics are found basically within the water-soluble parcel (Stintzing et al., 2005). 
Table 4. Antioxidant ratio of Cactus pear fruits pulp.

\begin{tabular}{llll}
\hline Treatment & TPC GAE $\mathbf{~ m g / 1 0 0 m L ) ~}$ & TFC GAE mg/100mL) & Vit. C (g AA/kg) \\
\hline T1 & $104.30 \pm 0.85^{\mathbf{a}}$ & $1.41 \pm 0.16^{\mathbf{c}}$ & $55.42 \pm 1.05^{\mathbf{a}}$ \\
T2 & $104.30 \pm 0.85^{\mathbf{a}}$ & $1.95 \pm 0.03^{\mathbf{a}}$ & $51.01 \pm 2.17^{\mathbf{b}}$ \\
T3 & $95.37 \pm 1.07^{\mathbf{b}}$ & $1.44 \pm 0.07^{\mathbf{b}}$ & $56.04 \pm 0.60^{\mathbf{a}}$ \\
\hline
\end{tabular}

*Average and standard Deviation of three replications

* Means within a row with different letters are significantly different at $\mathrm{P} \leq 0.05$.

The analyzed samples have significant content

of flavonoids' compounds since it was $1.95,1.44$ and $1.41 \pm 0.02 \mathrm{mg} / 100 \mathrm{ml}$ in $\mathrm{T} 2, \mathrm{~T} 3$ and $\mathrm{T} 1$, respectively. The statistical analysis showed that the analyzed samples were significantly different

$(\mathrm{P} \leq 0.05)$ for $\mathrm{T} 2$ which has the highest content of flavonoids. Meanwhile T1 had the lowest value. It was mention in the literature that all the tested cactus pear contained signific ant amounts of flavonoids, for

example isorhamnetin, quercetin, and luteolin and all these compounds are very effective antioxidants (Osuna-Martínez et al., 2014). similar results were .(reported by Santos-Zea et al. (2011

The antioxidant activity of assured foods depends on a combination action of antioxidants with diverse mechanisms i.e., synergistic interactions. Thence, it is essential to unite several methods to decide in vitro antioxidant capacity of food (Perez-Jimenez et al.,2008). The pulp of cactus pear had higher antioxidant values (measured by DPPH), in T2 than T3 and T1. Pulp of cactus pear in T2 exhibited higher levels compared to T3 than T1 in all concentrations (Fig 2). Similar observations were reported by Zafra-Rojas et al., (2013) who found convergence results for the all treatment in antioxidant compounds.

The results of Vit C content are presented in Table (4). Results showed that produced fruits under $\mathrm{T} 3$ and $\mathrm{T} 1$ contained higher levels of Vit $\mathrm{C}$ being 55.42 and $56.04 \mathrm{~g} \mathrm{AA} / \mathrm{kg}$ respectively than those obtained under T2. Obtained results are well fit with those values that were observed by ChavezSantoscoy et al. (2009) Vit.C is a good indicator of maturity and ready to use of the fruits and is a necessary antioxidant nutrient (Selli et al., 2002).

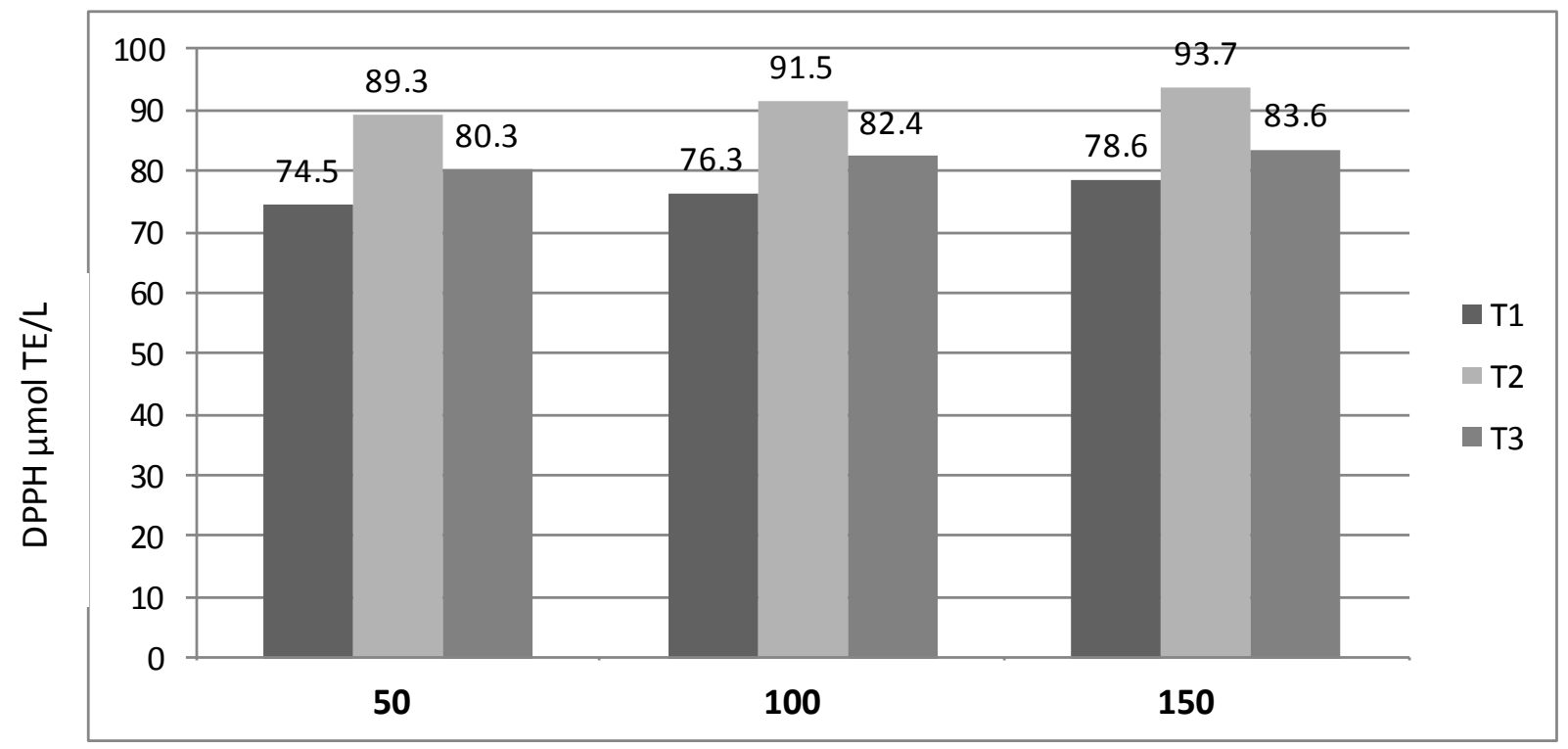

Extracts solution concentration $\mu \mathrm{L}$

Fig 2. Antioxidant ratio of Cactus pear fruits pulp.

\subsection{Sensory evaluation of cupcake.}

From the results presented in Table (5) and illustrated in Fig. (3) it could be noticed that C-, C3 and $\mathrm{C} 2$ treatments showed the highest overall acceptability and were found to be not significantly different. However, odor value and taste values of all treatments were found to be not significantly. No significant difference was observed for appearance in treatments of $\mathrm{C}-, \mathrm{C} 1, \mathrm{C} 2$ and $\mathrm{C} 3$. Treatments of $\mathrm{C}+, \mathrm{C} 1, \mathrm{C} 2, \mathrm{C} 3$, and $\mathrm{C} 4$ were found to be not significantly different in between for crust color. Although the ordinary color of the regular cupcake samples is completely different from the purple color of the cupcake with the addition of the cactus pear pulp, no significant difference between (40\%) followed by (60\%) addition and (C-) samples, that mean some panelists are linked by regular color of 
Table 5. Sensory evaluation of English cupcake made by using different levels of cactus pear pulp.

\begin{tabular}{|c|c|c|c|c|c|c|c|c|c|c|}
\hline \multirow[b]{2}{*}{ Sample } & \multirow[b]{2}{*}{ Appear (10) } & \multirow[b]{2}{*}{ crust color (10) } & \multirow{2}{*}{$\frac{\text { al appearance }}{\text { crumb color }}$} & \multicolumn{2}{|c|}{ Cell characte ristics } & \multicolumn{2}{|c|}{ Texture properties } & \multicolumn{2}{|c|}{ Other characteristics } & \multirow[b]{2}{*}{$\begin{array}{r}\text { Overall Accept. } \\
\text { (100) }\end{array}$} \\
\hline & & & & $\begin{array}{r}\text { uniformity } \\
(10)\end{array}$ & $\begin{array}{r}\text { size of cells } \\
(10)\end{array}$ & $\begin{array}{r}\text { Softness } \\
(10)\end{array}$ & moistness (10) & $\begin{array}{r}\text { Odor } \\
(10)\end{array}$ & $\begin{array}{r}\text { Taste } \\
(10)\end{array}$ & \\
\hline $\mathrm{C}$ - & $9.83 \pm 0.29^{a}$ & $9.83 \pm 0.28^{\mathrm{a}}$ & $19.34 \pm 0.58^{\mathrm{a}}$ & $9.16 \pm 0.28^{\mathrm{a}}$ & $9.33 \pm 0.57^{\mathrm{a}}$ & $7.00 \pm 0.1^{\mathrm{c}}$ & $7.66 \pm 0.59^{b c}$ & $9.67 \pm 0.60^{\mathrm{a}}$ & $8.84 \pm 0.29^{\mathrm{a}}$ & $90.67 \pm 0.76^{\mathrm{a}}$ \\
\hline $\mathrm{C}+$ & $8.66 \pm 0.29^{b c}$ & $8.5 \pm 0.86^{\mathbf{b}}$ & $17.68 \pm 0.57^{\mathbf{b c}}$ & $9.16 \pm 0.28^{\mathrm{a}}$ & $9.00 \pm 0.02^{\mathrm{a}}$ & $7.66 \pm 0.57^{\mathbf{b c}}$ & $7.33 \pm 0.57^{\mathrm{c}}$ & $9.34 \pm 0.57^{\mathrm{a}}$ & $8.83 \pm 0.57^{\mathrm{a}}$ & $86.16 \pm 1.44^{\mathrm{bc}}$ \\
\hline C1 & $9.16 \pm 0.27^{\mathbf{a b}}$ & $8.35 \pm 0.57^{\mathbf{b}}$ & $16.83 \pm 0.29^{c}$ & $9.00 \pm 0^{\mathbf{a}}$ & $9.00 \pm 0.0^{\mathrm{a}}$ & $7.33 \pm 0.56^{\mathrm{bc}}$ & $7.67 \pm 0.58^{\mathbf{b c}}$ & $9.65 \pm 0.52^{\mathrm{a}}$ & $9.33 \pm 0.28^{\mathrm{a}}$ & $86.34 \pm 1.04^{\mathrm{bc}}$ \\
\hline $\mathrm{C} 2$ & $9.83 \pm 0.28^{\mathrm{a}}$ & $9.34 \pm 0.29^{\mathbf{a b}}$ & $18.31 \pm 0.58^{\mathbf{a b}}$ & $7.33 \pm 0.58^{\mathrm{b}}$ & $8.33 \pm 0.58 \mathbf{a}$ & $8.00 \pm 0^{\mathbf{a b c}}$ & $8.34 \pm 0.29^{\mathbf{b}}$ & $9.66 \pm 0.58^{\mathrm{a}}$ & $9.66 \pm 0.25^{\mathrm{a}}$ & $88.84 \pm 1.15^{\mathrm{ab}}$ \\
\hline C3 & $9.84 \pm 0.29^{\mathbf{a}}$ & $8.66 \pm 0.57^{\mathbf{b}}$ & $19.35 \pm 0.55^{\mathrm{a}}$ & $7.33 \pm 0.57^{\mathbf{b}}$ & $8.00 \pm 1^{\mathrm{a}}$ & $9.00 \pm 0.5^{\mathrm{a}}$ & $9.32 \pm 0.28^{\mathrm{a}}$ & $9.65 \pm 0.55^{\mathrm{a}}$ & $9.67 \pm 0.27^{\mathrm{a}}$ & $90.84 \pm 1.25^{\mathrm{a}}$ \\
\hline C4 & $8.16 \pm 0.28^{c}$ & $8.35 \pm 0.27^{\mathbf{b}}$ & $18.31 \pm 0.29^{\mathbf{a b}}$ & $6.33 \pm 0.57^{\mathbf{b}}$ & $6.66 \pm 0.58^{\mathrm{b}} 8$ & $8.50 \pm 0.86^{\mathbf{a b}}$ & $9.67 \pm 0.27^{\mathrm{a}}$ & $9.67 \pm 0.57^{\mathrm{a}}$ & $9.00 \pm 0.86^{\mathrm{a}}$ & $84.50 \pm 2.29^{c}$ \\
\hline LSD & 0.5135 & 0.93761 & 0.8894 & 1.06904 & 1.02710 & 0.93761 & 0.72627 & 1.00547 & 0.86443 & 2.50712 \\
\hline
\end{tabular}

C- : control without any addition

C1:20\% Purple cactus pear pulp (CPP)

C3:60\% Purple cactus pear pulp (CPP)
C+ : controlusing Carmoisine (E-122) as synthetic color

C2:40\% Purple cactus pear pulp (CPP)

C4:80\% Purple cactus pear pulp(CPP)

*Average and standard Deviation of three replications

* Means within a row with different letters are significantly different at $\mathrm{P} \leq 0.05$. 


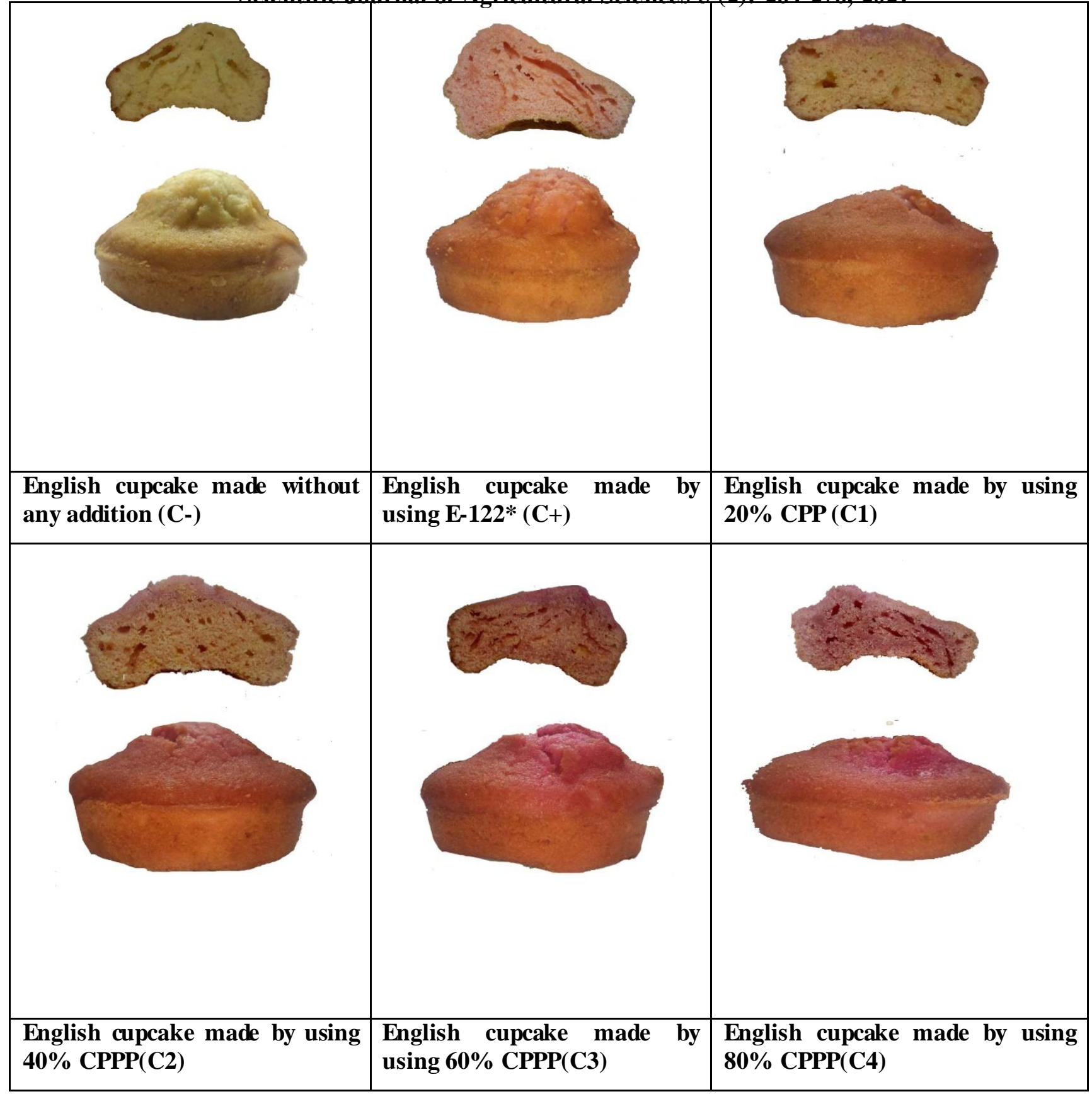

C- : control without any addition $\quad$ C+ : control using Carmoisine (E-122) as synthetic color C1:20\% Purple cactus pear pulp (CPP) C2:40\% Purple cactus pear pulp(CPP)

C3:60\% Purple cactus pear pulp (CPP) C4:80\% Purple cactus pear pulp(CPP)

Fig 3. English cupcake made from wheat flour by using different levels of cactus pear fruits pulp.

cake and some of them prefer purple new color but not up to $(60 \%)$ addition. In terms of odor and taste, no significant difference monitored between transactions. The results fixed that use of cactus pear pulp in cupcake process increase softness and moistness with almost no difference in size of cells.

\subsection{Physical properties of processed cupcake}

The results presented in Table (6) indicated that $\mathrm{C} 3, \mathrm{C} 1, \mathrm{C} 2$, and $\mathrm{C}$ - treatments showed the highest for weight which varied between 55.63 gm for $\mathrm{C} 3$ and $53.91 \mathrm{gm}$ for C- with no significant difference in between. However, volume values were found to be varied between $76.5 \mathrm{~cm} 3$ for $\mathrm{C} 4$ and $136.75 \mathrm{~cm} 3$ for $\mathrm{C} 1$. These results greatly affected the specific volume which showed values varied between 1.41 for $\mathrm{C} 4$ and 2.83 for $\mathrm{C} 1$.

Table 6. Physical properties of cake made by using different levels of cactus peal pulp 


\begin{tabular}{rccc}
\hline Sample & Weight $(\mathbf{g m})$ & Volume $\left(\mathbf{c m}^{\mathbf{3}}\right)$ & Specific volume $\left(\mathbf{c m}^{\mathbf{3}} / \mathbf{g m}\right)$ \\
\hline $\mathbf{C}-$ & $53.91 \pm 1.40^{\mathbf{a}}$ & $103 \pm 2.45^{\mathbf{b}}$ & $1.91 \pm 0.01^{\mathbf{b}}$ \\
$\mathbf{C}+$ & $51.69 \pm 0.41^{\mathbf{b}}$ & $88.5 \pm 1.29^{\mathbf{c}}$ & $1.71 \pm 0.02^{\mathbf{c}}$ \\
$\mathbf{C} 1$ & $55.19 \pm 1.64^{\mathbf{a}}$ & $136.75 \pm 3.30^{\mathbf{a}}$ & $2.84 \pm 0.13^{\mathbf{a}}$ \\
$\mathbf{C 2}$ & $54.94 \pm 0.56^{\mathbf{a}}$ & $107 \pm 5.29^{\mathbf{b}}$ & $1.95 \pm 0.08^{\mathbf{b}}$ \\
$\mathbf{C 3}$ & $55.63 \pm 1.54^{\mathrm{a}}$ & $90.5 \pm 3.11^{\mathbf{c}}$ & $1.63 \pm 0.02^{\mathbf{c}}$ \\
$\mathbf{C 4}$ & $54.26 \pm 0.59^{\mathbf{c}}$ & $76.5 \pm 1.29^{\mathbf{d}}$ & $1.41 \pm 0.01^{\mathbf{d}}$ \\
LSD & 1.7005 & 4.6155 & 0.0937 \\
\hline
\end{tabular}

C- : control without any addition $\quad$ C+ : control using Carmoisine (E-122) as synthetic color

C1:20\% Purple cactus pear pulp (CPP) C2:40\% Purple cactus pear pulp (CPP)

C3:60\% Purple cactus pear pulp (CPP) C4:80\% Purple cactus pear pulp(CPP)

*Average and standard Deviation of three replications

* Means within a row with different letters are significantly different at $\mathrm{P} \leq 0.05$.

\subsection{Texture properties of processed cupcake}

An increase in hardness, chewiness and gumminess values with adding cactus pear pulp was observed in all recipes as indicated in Table (7). A similar result was also obtained with other baked goods (Gómez-Conde et al., 2007). Chewiness is one of the texture parameters simply correlated with sensory evaluation analysis through trained panels (Esteller et al., 2004). Cohesiveness quantifies the inside resistance of food product structure. As happened with firmness, fresh English cupcake cohesiveness $w$ as affected by the added cactus pulp. Addition of $60 \%$ cactus pulp (C3) have showed a highest value of baked cakes. This must be related to intramolecular attraction between the pulp and pectin and other ingredients. A individual evaluation of springiness is generally implement by consumers while, consists of slightly pressing the part of food, by hand as well with the mouth with a view to verifying how easily it back to the original shape. Regarding springiness, a direct relationship was observed by increasing the proportion of cactus pear pulp ratio. A similar effect has been observed by using pectin as a source of hydrocolloids, and these colloids can also affect the quality of the final product (Gómez-Conde et al., 2007). Therefore, adding cactus pear pulp to the product mixture had a positive effect on the springiness properties of the manufactured cake.

Table 7.Texture properties of cake made by using different levels of cactus pear fruits pulp.

\begin{tabular}{lllllll}
\hline Sample & $\begin{array}{l}\text { Hardness } \\
(\mathbf{N})\end{array}$ & Cohesiveness & $\begin{array}{l}\text { Resilience } \\
(\mathbf{1 . 1 7})\end{array}$ & $\begin{array}{l}\text { Springiness } \\
(\mathbf{m m})\end{array}$ & $\begin{array}{l}\text { Gumminess } \\
(\mathbf{N})\end{array}$ & $\begin{array}{l}\text { Chewiness } \\
(\mathbf{M J})\end{array}$ \\
\hline $\mathbf{C}-$ & 6.36 & 2.19 & 1.14 & 0.46 & 16.30 & 7.5 \\
$\mathbf{C}+$ & 6.62 & 2.18 & 1.13 & 0.46 & 16.78 & 6.7 \\
$\mathbf{C 1}$ & 6.95 & 2.21 & 1.13 & 0.51 & 14.64 & 6.80 \\
$\mathbf{C 2}$ & 6.73 & 2.56 & 1.17 & 0.51 & 14.76 & 7.50 \\
$\mathbf{C 3}$ & 6.15 & 2.73 & 1.60 & 0.52 & 13.27 & 8.70 \\
$\mathbf{C 4}$ & 6.77 & 2.13 & 1.22 & 0.65 & 14.45 & 9.40 \\
\hline
\end{tabular}

C- : control without any addition $\quad$ C+ : control using Carmoisine (E-122) as synthetic color

C1:20\% Purple cactus pear pulp (CPP) C2:40\% Purple cactus pear pulp (CPP)

C3:60\% Purple cactus pear pulp (CPP) C4:80\% Purple cactus pear pulp(CPP)

\section{CONCLUSION}

Cactus pear plant could survive severe drought conditions producing high nutritional value fruits with high concentration of antioxidants and betacyanin's. Cactus pear fruits can add nutritional value to bakery products such as cupcakes. Supporting wheat flour with cactus pear pulp instead of synthetic colors could produce more nutritious cupcake. the prepared functional cupcake supported by cactus pear pulp improved cupcake flavor, chewiness, springiness, and resilience. However, further studies should be conducted to understand how to improve the organoleptic qualities of produced cupcakes supported by cactus pear pulp.

\section{Acknowledgment}

Authors would like to acknowledge the generous fund received from the European Union and the Egyptian Science and Technology Development Fund (STDF) through the project ID: ERANETMED3-204 to support the presented research study. 


\section{REFERENCE}

AACC (2010). Approved Methods of Analysis of American Association of Cereal Chemists international, 11th edition, St. Paul, Minnesota, USA.

AOAC (2012). Official Methods of Analysis (19thed.). Arlington, VA, USA: Association of Official Analytical Chemists.

Ahmad P, Sarwat M, Sharma S (2008). Reactive oxygen species, antioxidants and signaling in plants. J Plant Biol 51:167-173

Ajila CM, Leelavathi K, Prasada Rao UJS (2008). Improvement of dietary fiber content and antioxidant properties in soft dough biscuits with the incorporation of mango peel powder. Journal of Cereal Science, 48, 319-326.

Albano C, Negro C, Tommasi N, Gerardi C, Mita G, Miceli A, De Bellis L, Blando F (2015). Betalains, phenols and antioxidant capacity in cactus pear [Opuntia ficusindica (L.) Mill.] fruit from Apulia (South Italy) genotypes. Antioxidants 4, 269-280. https://doi.org/10.3390/antiox4020269

Barbera G, Carimi F, Inglese P (1992). Past and present role of prickly pear (Opuntia ficus-indica (L.) Miller, Cactaceae). Agriculture of Sicily. Econ. Bot. 46, 10-22.

Betancourta C, Cejudo-Bastanteb MJ, Herediab FJ, Hurtadoa N (2017). Pigment composition and antioxidant capacity of betacyanin's and betaxanthins fractions of Opuntia dillenii (Ker Gawl) Haw cactus fruit. Food Research International $\quad .101 \quad, 173-179$. https://doi.org/10.1016/j.foodres. 2017.09.007

Butera D, Tesoriere L, Di Gaudio F (2002). Antioxidant activities of Sicilian prickly pear (Opuntia ficus indica) fruit extracts and reducing properties of its betalains: betanin and indicaxanthin, J. Agric. Food Chem. 50, 6895690110.1021/jf025696p

Cantwell M (1991). Quality and post-harvest physiology of 'nopalitos' and 'tunas'. In: Proceedings of the Second Annual Texas Prickly Pear Conference. McAllen, Texas.

Cassano A, Conidi C, Drioli E (2010), Physicochemical parameters of cactus pear (Opuntia ficusindica) juice clarified by microfiltration and ultrafiltration processes. Desalination 250,11011104. https://doi.org/10.1016/j.desal.2009.09.117

Cassano A, Conidi C, Timpone R, Avella MD, Drioli E. (2007). A membrane-based process for the clarification and the concentration of the cactus pear juice, J. Food Eng. 80 914-921. https://doi.org/10.1016/j.jfoodeng.2006.08.005

Cayupán CYS, Ochoa MJ, Nazareno MA (2011). Health-promoting substances and antioxidant properties of Opuntia sp. fruits. Changes in bioactive-compound contents during ripening process. Food Chem. 126, 514-519. https://doi.org/10.1016/j.foodchem.2010.11.033

Chaiya, B, Pongsawatmanit R (2011). Quality of batter and sponge cake prepared from wheattapioca flour blends. Kasetsart Journal (Natural Science), 45, 305-313.

Chavez-Santoscoy R A, Gutierrez-Uribe JA, Serna-Saldı'var S O (2009). Phenolic composition, antioxidant capacity and in vitro cancer cell cytotoxicity of nine prickly pear (Opuntia spp.) juices. Plant Foods for Human Nutrition 64, 146-152.

Cruz-Cansino NS, Ramírez-Moreno E, LeónRivera JE, Delgado-Olivares L, Alanis-Garcia E, Ariza-Ortega JA, Manríquez-Torres JJ, Jaramillo-Bustos DP(2015). Shelf life, physicochemical, microbiological and antioxidant properties of purple cactus pear (Opuntia ficus indica) juice after thermoultrasound treatment. Ultrason Sonochem. 27, 277-286. https:// 10.1016/j.ultsonch.2015.05.040

DeWit M, Hugo A, Shongwe N, Van der Merwe $\mathbf{R}$ (2016). Effect of cultivar, season and locality on lipid content and fatty acid composition of cactus pear seed oil. South African Journal of Plant and Soil 33, 279-288. https://doi.org/10.1080/02571862.2016.1141335

Djeridane A, Yousfi M, Nadjemi B, Boutassouna D, Stocker P, Vidal N (2006). Antioxidant activity of some Algerian medicinal plants extracts containing phenols compounds. Journal of Food Chemistry. 97: 654-660.

Du Toit A, De Wit M, Naudé S, Taljaard M, Fouché HJ, Hugo A (2019). Functional properties and sensory evaluation of mucilage from SouthAfric an cactus pear cladodes. Acta Hortic Proc 9th IC Cactus Pear Cochineal; (1247):251-60. 10.17660/ActaHortic.2019.1247.34

El-Said AA, Hassan A, Askar SH, Askar A (1993). An alternative formula for the sweetening of reduced-calorie cakes. Food Chemistry, 48, 169- 172.

Galizzi FA, Felker P, González C, Gardiner D (2004). Correlations between Soil and Cladode Nutrient Concentrations and Fruit Yield and Quality in Cactus Pears, Opuntiaficus-indica in a Traditional Farm Setting in Argentina. Journal of Arid Environments, 59, 115-132. https://doi.org/10.1016/i. jaridenv.2004.01.015

Gómez-Conde MS. García .J. Chamorro S. Eiras P, Rebollar PG, Pérez de Rozas A, Badiola I, de Blas C, Carabaño R (2007). Neutral detergentsoluble fiber improves gut barrier function in twenty-five-day-old weaned rabbits. J. Anim. Sci., 85 (12): 3313-3321 10.2527/jas.2006-777

Gould JM, Jasberg BK, Dexter LB, Hsu JT, Lewis SM, Fahey-JR G C (1989). High-fiber, 
noncaloric flour substitute for baked foods. Properties of alkaline peroxide treated lignocelluloses. Cereal Chemistry, 66(3), 201-205. Jacob JK, Hakimuddin F, Paliyath G, Fisher H (2008). Antioxidant and antiproliferative activity of polyphenols in novel high-polyphenol grape lines. Food Res. Int. 41, 419-428. https://doi.org/10.1016/j.foodres.2008.02.009

Karababa E, Coşkuner Y, Aksay S (2004). Some physical fruit properties of cactus pear (Opuntia spp.) that grow wild in the Eastern Mediterranean region of Turkey. Journal of the Professional Association for Cactus Development, 6,1-8.

Kivrak I (2015). Analytical Methods Applied to Assess Chemical Composition, Nutritional Value and in Vitro Bioactivities of Terfezia Olbiensis and Terfezia Claveryi from Turkey, Food Anal. Methods, 8, 1279-1293.

Kobylewski S, Jacobson M F (2012). Toxicology of food dyes." International. Journal of occupational and environmental health 18.3: 220246. 10.1179/1077352512Z.00000000034.

Livrea MA, Tesoriere L (2006). Health benefits and bioactive components of fruits of Opuntia ficus-indica [L.] Mill. J. PACD 8 (2006) 73-90.

Mashope B K (2007). "Characterization of cactus pear germplasm in South Africa", Department of Plant Sciences, University of the Free State, South Africa. Ph.D.. 2007.

Mohr BC, Mohr CL (2000), The Mohr Digi-Test (MDT) computerized agricultural penetrometer as an apple maturity tool8 Oct. 2010

MOUSSA-AYOUB TE, SAMAHY EL, ROHN SK, KROH S (2011). Flavonols, betacyanin's content and antioxidant activity of cactus Opuntia macrorhiza fruits. Food Res. Int. 44, 2169-2174. https://doi.org/10.1016/j.foodres. 2011.02.014

\section{Osuna-Martínez U, Reyes-Esparza J,} Rodríguez-Fragoso L, (2014). Cactus (Opuntiaficus-indica): a review on its antioxidant's properties and potential pharmacologicaluse in chronic diseases. Nat. Prod. Chem. Res. 2 (6), 1-8. Ott $\mathrm{H} \mathrm{W}$ (1988). Noise $\mathrm{R}$ duction Tech-niques in Ele ctronicsystems. 2nd ed. John Wiley and Sons.

Perez-Jimenez J, Arranz S, Tabernero M, DiazRubio ME, Serrano J, Goni, F.Saura-Calixto I (2008).Updated methodology to determine antioxidant capacity inplant foods, oils and beverages: extraction, measurement and expression of results. Food Res. Int. 41 274-285. https://doi.org/10.1016/j.foodres.2007.12.004

Piga A (2004). Cactus pear: a fruit of nutraceutical and functional importance. J. Prof. Assoc. Cactus D. 6, 9-22.

Potgieter JP, Mkhari JJ (2002). Evaluation of cactus pear (Opuntia spp.) germplasm for fruit production purposes. Combined Congress, 15-17 Januarv. Pietermaritzburg. Kwazulu/Natal.

Rodríguez L, Lopez DJ, Preston TR, Peters K (2006). New Cocoyam (Xanthosoma sagittifolium) leaves as partial replacement for soya bean meal in sugar cane juice diets for growing pigs. Livest. Res. Rural Dev., 18 (7)

Romjaun ZZ, Prakash J (2013). Development and Assessment of Fibre-Enriched Muffins. Adv. Food Sci., 35(4), 159-165.

Sakuta M (2014). Diversity in plant red pigments: anthocyanins and betacyanin's. Plant Biotechnology Reports, no. 1 (2014):37-48

Santos-Zea L, Gutie' rrez-Uribe JA, SernaSaldivar SO (2011). Comparative anal-yses of total phenols, antioxidant activity, and flavonol glycoside profile of cladode flours from different varieties of Opuntia spp. Journal of Agricultural and Food Chemistry 59, 7054-7061.

Sapers GM, Douglas FW (1987). Measurement of enzymatic browning at cut surfaces and in juice of raw apple and pear fruits. J. Food Sci., 52: 12581285. https://doi.org/10.1111/j.1365-

2621.1987.tb14057

Selli S, Canbas A, Unal U (2002). Effect of bottle colour and storage conditions on browning of orange wine. Nahrung Food (46): 64-67.

Shea T (2020). Four incredibly harmful effects artificial dyes have on our health. FoodNerd:www.researchgate.net/public ation/2317 40794_Toxicology_of_food_dyes .

Stintzing FC, Herbach KM, Mosshammer MR, Carle RW, Sellappan S, Akoh CC, Bunch R, Felker $P$ (2005). Color, Betalain Pattern, and Antioxidant Properties of Cactus Pear (Opuntia spp.) Clones. J. Agric. Food Chem. 2005, 53, 442-451 10.1021/jf048751y.

Sumaya-martinez MT, Cruz-jaime S, MadrigalSantillan E, Garcia- Paredes JD, Carino-cortes R, Cruz-cansino N, Valadez-Vega C, MartinezCardenas L, Alanis-Garcia E (2011). Asc orbic acid, phenolic contents and antioxidant properties of purple, red, yellow and white cactus pears. Int. J. Mol. Sci. 12, 6452-6468. 10.3390/ijms12106452 Zafra-Rojas QY, Cruz-Cansino N, RamirezMoreno E, Delgado-Olivares L, VillanuevaSanchez J, Alanis-Garcia E (2013). Effects of ultrasound treatment in purple cactus pear (Opuntia ficus-indica) juice. Ultrasonics Sonochemistry, 20(5), 1283-1288

Zarroug MB, Baraket G, Zourgui L, Souid S, Salhi A (2015). Genetic diversity and phylogenetic relationship among Tunisian cactus species (Opuntia) as revealed by random amplified microsatellite polymorphism markers. Genetics and Molecular Research.1:1423-1433. 
الملخص العربي

\section{استخدام ثمار التين الشوكي المنزرعة تحت ظرف الجفاف الشديد كمصدر طبيعي للأصباغ ومضادات الأكسدة في تصنيع كيك}

محمود الوكيل' ، محمد حسن حسني"، محمد رشادّ و مها البناء؛

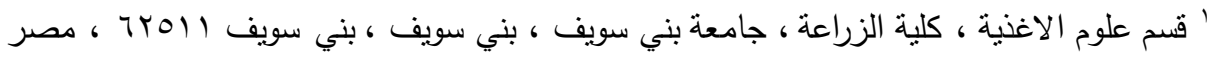

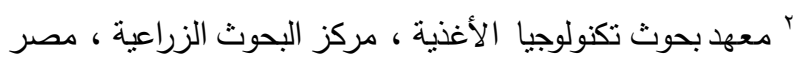

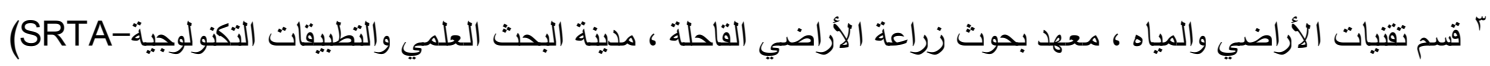

$$
\text { (City) }
$$

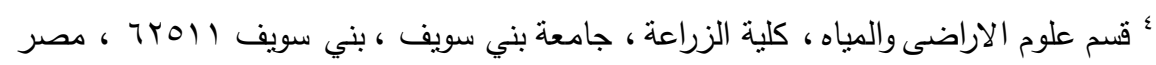

يعتبر التين الثثوكي من النباتات السائدة في الأراضي القاحلة والتي تتمتع ثمارها بقيمة غذائية مرتفعة. تستخدم ثمار التين الثوكي في رفع

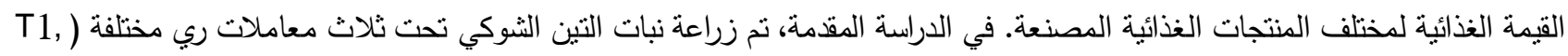
(T2, T3

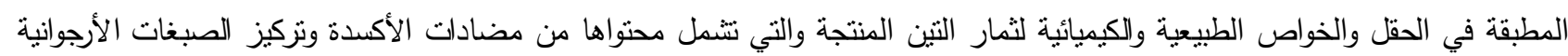

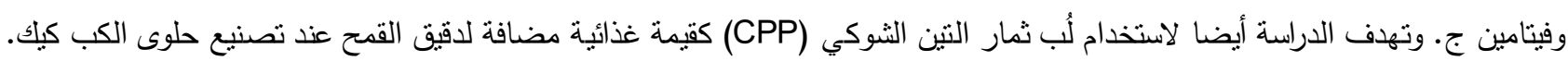

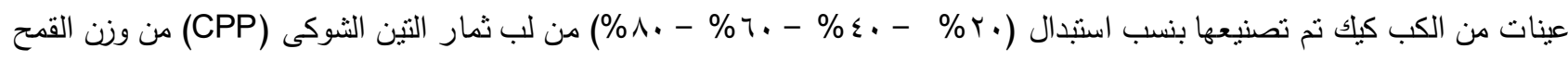
المستخدم. الثمار المنتجة تحت معاملات الري T2 و T3 كانت الأعلى في تركيز الصبغة الأرجوانية ومضادات الأكسدة (محتوى الفينول والفلافينويد TPC

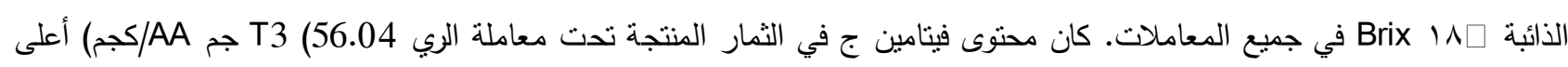

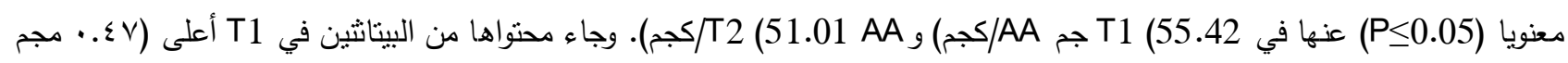

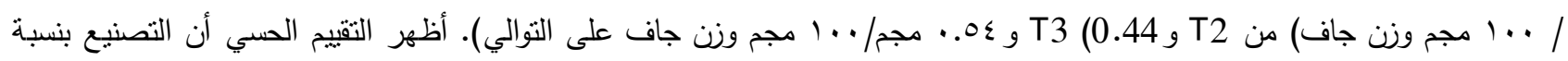

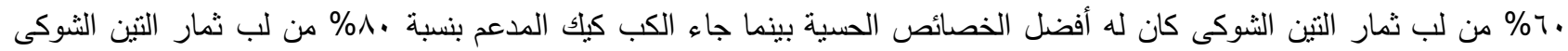

